\title{
Pengujian Viabilitas dan Vigor Benih Kecipir (Psophocarpus tetragonolobus L.)
}

Seed Viability and Vigor Testing of Winged Bean (Psophocarpus tetragonolobus L.)

\author{
Efris Zason Purba dan Tatiek Kartika Suharsi*
}

Departemen Agronomi dan Hortikultura, Fakultas Pertanian, Institut Pertanian Bogor (Bogor Agricultural University), J1. Meranti, Kampus IPB Darmaga, Bogor 16680, Indonesia Telp.\&Faks. 62-251-8629353 e-mail agronipb@indo.net.id

*Penulis untuk korespondensi : tatiekkartika@yahoo.co.id

Disetujui 16 Januari 2017/ Published Online 24 Januari 2017

\begin{abstract}
Winged bean is a potential indigenous vegetable as a companion crop to fulfill national needs for soybean. Winged bean seed production has to be maintained continuously through the seed testing. The objective of this research were to learn the methods of seed planting and the best medium in testing the viability and vigor of winged bean. This research was conducted at IPB Seed Storage and Quality Testing Laboratory on September 2015 until January 2016. The methods of seed planting on CD paper 2 rows, CD paper 5 rows and straw paper 2 rows should be used for winged bean seed testing because gave a high yield for maximum growth potential, germination percentage, normal seedling dry weight, vigor index and the growth speed. Seed planting method on sand medium (top sand) should be used while the seed testing applied without paper medium. There is positive correlation between germination percentage of normal seedling dry weight, and vigor index of growth speed. This indicates that the method of planting was done, could predicted one of the benchmarks value by knowing the value of the other benchmarks.
\end{abstract}

Keywords : CD paper, correlation, potential, sand, straw paper

\begin{abstract}
ABSTRAK
Tanaman kecipir merupakan sayuran indigenous yang potensial sebagai tanaman pendamping dalam memenuhi kebutuhan nasional terhadap kedelai. Produksi benih kecipir secara terus menerus diupayakan melalui pengujian benih. Penelitian ini bertujuan untuk mempelajari metode penanaman benih dan media yang terbaik dalam pengujian viabilitas dan vigor benih kecipir. Penelitian dilaksanakan di Laboratorium Penyimpanan dan Pengujian Mutu Benih IPB pada bulan September 2015 - Januari 2016. Metode penanaman benih pada kertas CD 2 baris, CD 5 baris dan kertas merang 2 baris dapat digunakan sebagai metode penanaman pada pengujian benih kecipir karena menghasilkan potensi tumbuh maksimum, daya berkecambah, bobot kering kecambah normal, indeks vigor dan kecepatan tumbuh yang tinggi. Metode penanaman pada media pasir (top sand) dapat digunakan pada pengujian benih tidak menggunakan substrat kertas. Korelasi positif terjadi antara tolok ukur daya berkecambah terhadap bobot kering kecambah normal, dan indeks vigor terhadap kecepatan tumbuh. Hal ini mengindikasikan bahwa dengan metode penanaman yang dilakukan, kita dapat memprediksi nilai salah satu tolok ukur dengan mengetahui nilai tolok ukur lainnya.
\end{abstract}

Kata kunci : kertas CD, kertas merang, korelasi, pasir, potensial 


\section{PENDAHULUAN}

Tanaman kecipir termasuk sayuran indigenous, potensial dikembangkan (Handayani 2013). Tanaman kecipir dapat menjadi pendamping kedelai dalam memenuhi kebutuhan nasional akan bahan baku pembuatan tempe, tahu, kecap maupun susu. Keberadaan tanaman kecipir di Indonesia saat ini sudah jarang ditemui dan biasanya ditanam sebagai tanaman pagar di pekarangan rumah. Meninjau potensi yang dimiliki, tanaman kecipir perlu tetap dilestarikan dengan menjaga keberlanjutan produksinya. Mencapai produksi kecipir yang tinggi tidak terlepas dari kebutuhan benih yang bermutu dan benih bermutu tinggi hanya dapat dideteksi melalui pengujian benih.

Budidaya tanaman di lapangan pada umumnya menggunakan benih sebagai bahan perbanyakan. Mutu benih yaitu mutu fisik, mutu fisiologis dan mutu genetik sangat perlu diketahui sebelum dilakukan penanaman di lapangan. Mutu fisiologis benih adalah tinggi rendahnya daya hidup atau viabilitas dan vigor benih yang tercermin dari daya berkecambah, bobot kering kecambah normal, indeks vigor, kecepatan tumbuh dan keserempakan tumbuh (Widajati et al. 2013). Menurut Direktorat Jenderal Tanaman Pangan (2009) benih kacang-kacangan seperti benih kacang kedelai, kacang tanah dan kacang hijau minimal harus memiliki daya berkecambah $80 \%$ sebagai salah satu syarat kelulusan sertifikasi benih. Mutu benih yang tinggi akan berpengaruh terhadap peningkatan produksi tanaman.

Pengujian mutu benih merupakan hal yang penting dilakukan dalam mendapatkan benih yang bermutu. Menurut ISTA (2014), media/substrat yang digunakan dalam pengujian mutu benih diantaranya kertas filter, kertas towel, kertas blotter, pasir dan media pertumbuhan organik. Ketersediaan media kertas filter, towel dan blotter di Indonesia masih terbatas. Untuk menyesuaikan alat dan bahan pengujian yang ada di ISTA, pengujian mutu benih kecipir menggunakan media kertas yang biasa dipakai di Indonesia yaitu kertas merang dan kertas CD. Pasir dan arang sekam juga dapat digunakan selain media kertas saat pengujian.

Budidaya kecipir di Indonesia saat ini masih menggunakan benih yang belum bersertifikat. Para petani menggunakan benih kecipir tanpa mengetahui mutu benihnya. Kondisi tersebut mengakibatkan produksi kecipir sulit diprediksi, bahkan produksinya dapat dibawah ekspektasi petani. Untuk menghindari keadaan tersebut, petani harus mengetahui tinggi rendahnya mutu benih kecipir yang digunakan.
Oleh karena itu, perlu dipelajari bagaimana metode yang tepat dalam pengujian mutu benih kecipir. Melalui metode pengujian yang tepat, petani akan mendapatkan informasi mutu benih seperti apa yang baik digunakan di lapangan. Penelitian ini bertujuan untuk mempelajari kombinasi metode penanaman benih dan media perkecambahan benih yang paling baik untuk digunakan dalam pengujian viabilitas dan vigor benih kecipir.

\section{METODE PENELITIAN}

Penelitian dilaksanakan pada bulan September 2015 hingga Januari 2016 di Laboratorium Pengujian Mutu Benih dan Penyimpanan Benih, Departemen Agronomi dan Hortikultura, Fakultas Pertanian, Institut Pertanian Bogor. Bahan tanaman yang digunakan adalah 3 lot benih kecipir dari 3 daerah yang berbeda yaitu Kabupaten Tulangbawang, Kabupaten Lampung Selatan dan Kabupaten Pesawaran. Benih masing-masing daerah dipanen pada tanggal yang berbeda. Pasir berukuran 1 $\mathrm{mm}$, arang sekam, kertas merang, kertas CD sebagai substrat perkecambahan, bahan lainnya adalah label, plastik, larutan natrium hipoklorit $3 \%$, aquades. Alat yang digunakan adalah oven, desikator, penggaris, mikrometer sekrup, handsprayer, kulkas, saringan pasir, bak pasir plastik, alat pengepres kertas IPB 75-1, alat pengecambah benih tipe IPB 72-1 dan autoclave.

Percobaan dilakukan dalam rancangan acak lengkap (RAL) satu faktor yang merupakan kombinasi antara media perkecambahan dan cara penanaman. Percobaan terdiri dari 8 perlakuan, yakni metode penanaman pada kertas CD cara 2 baris, CD cara 5 baris, kertas merang cara 2 baris, merang cara 5 baris, pasir top sand, pasir in sand, sekam top sand dan sekam in sand. Percobaan dilakukan sebanyak 3 ulangan, sehingga terdapat 72 satuan percobaan. Setiap satuan percobaan menggunakan 25 butir benih kecipir. Analisis data menggunakan uji $\mathrm{F}$, dan jika terdapat pengaruh yang nyata maka dilakukan uji lanjut DMRT (Duncan Multiple Range Test) pada taraf $5 \%$.

Percobaan diawali dengan melakukan beberapa percobaan pendahuluan, seperti pemilahan benih, penyaringan pasir dan arang sekam, sterilisasi media, skarifikasi permukaan kulit benih dan penguian viabilitas awal benih kecipir. Pemilahan benih dilakukan secara manual untuk memisahkan benih berdasarkan warna benih, ukuran benih dan bentuk fisik benih, sehingga diperoleh benih yang lebih seragam. Penyaringan pasir dan arang sekam dilakukan 
dengan menggunakan ayakan berukuran $1 \mathrm{~mm}$. Pasir dan sekam yang lolos dari saringan nantinya akan digunakan sebagai media perkecambahan dalam pengujian benih kecipir.

Sterilisasi media dilakukan pada pasir dan arang sekam dengan menggunakan autoclave. Pasir dan arang sekam dimasukkan ke dalam plastik tahan panas sebanyak 2 lapis untuk mengantisipasi kebocoran plastik. Media dalam plastik diikat dengan karet gelang dan diusahakan tidak ada ruang udara yang terbentuk. Proses sterilisasi dilakukan untuk mengurangi mikroorganisme yang dapat mengganggu perkecambahan benih kecipir.

Benih kecipir yang keras dapat menghambat pertumbuhan benih menjadi kecambah dan hal ini perlu dicegah dengan melakukan pematahan dormansi. Menurut Rahayu (2015), skarifikasi merupakan teknik pematahan dormansi kecipir yang terbaik dibandingkan perendaman pada larutan $\mathrm{KNO} 3 \quad 0.5 \%$ dan perendaman pada air panas suhu $50^{0} \mathrm{C}$. Skarifikasi benih kecipir dilakukan tepat sebelum penanaman dengan menggosok punggung benih menggunakan kertas amplas hingga permukaan kulit beniihnya semakin tipis. Permukaan kulit benih yang tipis diharapkan dapat mempercepat imbibisi air pada benih sehingga benih dapat berkecambah.

Pengujian viabilitas awal benih kecipir diuji dengan mengamati daya berkecambahnya. Pengujian viabilitas awal dilakukan pada kertas $\mathrm{CD}$ dengan cara penanaman 5 baris. Penanaman masing-masing lot hanya dilakukan sebanyak 2 ulangan karena keterbatasan jumlah benih. Tiap ulangan ditanam 25 butir benih, sehingga digunakan 50 butir benih kecipir untuk tiap lotnya.

Pengujian viabilitas dan vigor benih kecipir dilakukan pada 2 tipe media perkecambahan, yaitu media kertas (kertas CD dan merang) serta media bukan kertas (pasir dan arang sekam). Penanaman pada media kertas dilakukan dengan metode uji kertas digulung didirikan dalam platik (UKDdp). Kertas yang akan digunakan terlebih dahulu dilembabkan dengan cara merendam kertas menggunakan akuades, kemudian kertas dipres dengan alat pengepres kertas IPB 75-1. Jumlah kertas yang digunakan sebanyak 6 lembar kertas per media. Tiga lapis kertas sebagai alas bawah dan tiga lapis kertas sebagai penutup. Penanaman pada media kertas ada 2 cara, yaitu cara penanaman 2 baris dan 5 baris. Posisi benih pada cara penanaman 2 baris terletak di bagian tengah kertas. Benih yang ditanam dengan cara penanaman 5 baris disusun 5 butir benih tiap barisnya. Posisi benih untuk cara penanaman 2 baris maupun 5 baris dilakukan secara zig-zag.

Penanaman pada media bukan kertas (pasir dan sekam) dilakukan pada bak plastik (panjang: $26.5 \mathrm{~cm}$; lebar: $19 \mathrm{~cm}$ dan tinggi: $8 \mathrm{~cm}$ ) yang sudah diisi pasir maupun sekam dengan ketinggian $\pm 5 \mathrm{~cm}$. Penanaman pada pasir dan arang sekam dilakukan secara 5 baris, namun benih ditanam dengan kedalaman yang berbeda sesuai cara tanamnya. Cara tanam pada media bukan kertas ada 2 cara yaitu cara top sand (benih ditanam pada kedalaman $\pm 0.5 \mathrm{~cm}$ ) dan in sand (benih ditanam pada kedalaman $\pm 2 \mathrm{~cm}$ ). Pengamatan penelitian ini meliputi persentase kecambah hipokotil pendek (\%KHP), persentase kecambah hipokotil normal (\%KEN), persentase kecambah hipokotil panjang (\% KHPj), potensi tumbuh maksimum, daya berkecambah (DB), berat/bobot kering kecambah normal (BKKN), indeks vigor (IV), kecepatan tumbuh (KCT), panjang akar, diameter hipokotil, korelasi DB dan BKKN, serta korelasi IV dan KCT.

\section{HASIL DAN PEMBAHASAN}

\section{Kondisi Umum Benih dan Viabilitas Awal Benih Kecipir}

Benih kecipir yang digunakan merupakan hasil pemanenan polong kecipir yang berasal dari Kabupaten Lampung Selatan (lot 1), Kabupaten Tulangbawang (lot 2) dan Kabupaten Pesawaran (lot 3) pada bulan Juli 2015. Polong yang dipanen dijemur langsung dibawah sinar matahari dari jam 9.00 - 13.00 WIB. Ekstraksi benih dilakukan setelah penjemuran untuk mendapatkan biji kecipir sebagai benih yang akan digunakan. Warna benih yang didapat setelah ekstraksi didominasi benih berwarna cokelat muda, namun ada juga yang berwarna cokelat tua dan bahkan hitam. Ketiga lot benih yang digunakan untuk pengujian benih menggunakan warna yang sama yaitu benih berwarna coklat muda.

Bentuk benih juga tidak seluruhnya sama, ada yang kisut, agak pipih namun didominasi bentuk bulat. Sortasi benih dilakukan secara manual dan benih yang diperoleh didominasi bentuk yang bulat. Benih hasil sortasi kemudian ditimbang bobot 100 butirnya. Bobot 100 butir benih lot Lampung Selatan adalah $36.58 \mathrm{~g}$, lot Tulangbawang adalah $36.64 \mathrm{~g}$ dan lot Pesawaran adalah $37.26 \mathrm{~g}$.

Benih disimpan sejak bulan Juli sampai bulan September 2015 pada kondisi ruang penyimpanan benih yang menggunakan alat air conditioner (AC), sehingga suhu dan kelembabannya lebih terkontrol dan tidak terlalu berfluktuasi. Suhu pada ruang simpan berkisar 
antara $16-21{ }^{0} \mathrm{C}$ dan kelembaban berkisar antara 53-61\%. Benih yang akan disimpan dibungkus dengan 2 lapis plastik kemudian dimasukkan ke dalam toples plastik.

Sertifikasi untuk benih kecipir di Indonesia belum pernah dilakukan, sedangkan beberapa tanaman legum lainnya sudah ada. Menurut Ditjen Pangan (2009), standar daya berkecambah benih pada kacang- kacangan seperti kacang kedelai, kacang tanah dan kacang hijau yaitu $\geq 80 \%$. Sedangkan untuk koro pedang dan kacang merah minimal harus memiliki daya berkecambah $70 \%$. Hasil pengujian viabilitas awal benih kecipir menunjukkan bahwa daya berkecambah pada lot Lampung Selatan yaitu sebesar $76 \%$, lot Tulangbawang sebesar $86 \%$ dan lot Pesawaran sebesar 90\%.

Tabel 1. Daya berkecambah awal benih kecipir lot Lampung Selatan, lot Tulangbawang dan lot Pesawaran

\begin{tabular}{|c|c|c|c|c|c|c|c|c|c|c|c|c|}
\hline \multirow{2}{*}{ Ulangan } & \multicolumn{3}{|c|}{ Kecambah Normal } & \multicolumn{3}{|c|}{ Kecambah Abnormal } & \multicolumn{3}{|c|}{ Benih mati } & \multicolumn{3}{|c|}{ DB (\%) } \\
\hline & LS & TB & PS & $\mathrm{LS}$ & TB & PS & $\mathrm{LS}$ & TB & PS & LS & TB & PS \\
\hline 1 & 18 & 22 & 23 & 5 & 2 & 1 & 2 & 1 & 1 & 72 & 88 & 92 \\
\hline 2 & 20 & 21 & 22 & 5 & 3 & 3 & 0 & 1 & 0 & 80 & 84 & 88 \\
\hline
\end{tabular}

Keterangan : DB=Daya berkecambah; LS= Lampung Selatan; TB= Tulangbawang; PS= Pesawaran

Perbedaan daya berkecambah tiap lot mungkin dipengaruhi kualitas individu benih itu sendiri yang menyebabkan perbedaan kualitas benih antar lot untuk tumbuh menjadi kecambah normal. Adapun serangan cendawan hanya sedikit ditemukan pada tiap lot benih (Tabel 1).

\section{Pengaruh Metode Penanaman Benih dan Substrat Perkecambahan terhadap Pertumbuhan Kecambah (Panjang Hipokotil)}

Pengamatan persentase kecambah hipokotil pendek (\% KHP), kecambah hipokotil normal (\%KHN) dan kecambah hipokotil panjang (\%KHPj) hanya dilakukan pada dua lot benih (benih asal Kabupaten Tulangbawang dan Kabupaten Pesawaran) dikarenakan jumlah benih pada lot benih asal Lampung Selatan tidak mencukupi untuk pengamatan. Angka \% KHP menggambarkan persentase kecambah abnormal dengan panjang hipokotil $<4 \mathrm{~cm}$. Angka $\% \mathrm{KHN}$ menggambarkan persentase kecambah normal dengan panjang hipokotil $4-4.5 \mathrm{~cm}$ dan angka $\%$ KHPj menggambarkan persentase kecambah normal dengan panjang hipokotil > $4.5 \mathrm{~cm}$. Semakin tinggi angka \%KHPj, maka menandakan bahwa metode penanaman memiliki pengaruh yang baik dalam menghasilkan kecambah dengan hipokotil yang panjang. Begitupun sebaliknya, bila angka \%KHP tinggi, itu berarti metode penanaman memiliki pengaruh yang tidak baik terhadap performa hipokotil kecambahnya.

Persentase kecambah hipokotil pendek (\% $\underline{\text { KHP). }}$. Hasil analisis ragam pada Tabel 2 menunjukkan bahwa metode penanaman berpengaruh nyata terhadap \%KHP lot Tulangbawang dan berpengaruh sangat nyata terhadap \%KHP lot Pesawaran. Persentase kecambah hipokotil pendek (\% KHP) tertinggi pada benih lot Tulangbawang dihasilkan oleh media kertas merang dengan metode penanaman benih 5 baris, yaitu $13.3 \%$. Hasil ini berbeda nyata dengan metode penanaman pada kertas merang 2 baris yang tidak menghasilkan satupun kecambah dengan hipokotil pendek. Penanaman pada media arang sekam dengan cara penanaman top sand dan in sand menghasilkan \%KHP yang termasuk tinggi, yaitu $6.7 \%$ untuk top sand dan $8.9 \%$ untuk in sand. Kedua metode penanaman tersebut tidak berbeda nyata dengan penanaman pada kertas merang 5 baris.

Persentase kecambah hipokotil pendek (\%KHP) tertinggi pada benih lot Pesawaran dihasilkan oleh media sekam dengan metode penanaman top sand dan in sand, yaitu $15.5 \%$ untuk top sand dan $37.7 \%$ untuk in sand. Tingginya angka \%KHP pada media sekam diduga karena kemampuan media arang sekam kurang menyimpan air, sehingga petumbuhan kecambah lambat karena media kering. 
Tabel 2. Pengaruh perlakuan terhadap kecambah hipokotil pendek, kecambah hipokotil normal dan kecambah hipokotil panjang kecipir pada lot Tulangbawang dan lot Pesawaran

\begin{tabular}{|c|c|c|c|c|c|c|}
\hline \multirow{2}{*}{ Perlakuan } & \multicolumn{2}{|c|}{$\%$ KHP } & \multicolumn{2}{|c|}{$\% \mathrm{KEN}$} & \multicolumn{2}{|c|}{$\% \mathrm{KHPi}$} \\
\hline & Lot TB & Lot PS & Lot TB & Lot PS & Lot TB & Lot PS \\
\hline \multicolumn{7}{|c|}{------------------ $\%$------------------- } \\
\hline CD 2 baris & $2.2(23.8) b$ & $2.2(16.1) b$ & $6.7(27.6) b$ & $0(20.9)$ & $91.1 \mathrm{a}$ & $97.8 \mathrm{a}$ \\
\hline CD 5 baris & $2.2(23.8) b$ & $0(12.3) b$ & $4.4(24.8) b$ & $4.4(26.6)$ & $93.3 \mathrm{a}$ & $95.6 \mathrm{a}$ \\
\hline Merang 2 baris & $0(20.9) b$ & $2.2(16.1) b$ & $8.9(28.6) b$ & $17.8(33.4)$ & $86.7 \mathrm{a}$ & $80.0 \mathrm{a}$ \\
\hline Merang 5 baris & $13.3(32.1) \mathrm{a}$ & $2.2(16.1) b$ & $4.4(26.6) \mathrm{b}$ & $8.9(28.6)$ & $80.0 \mathrm{a}$ & 88.9 a \\
\hline Pasir TopSand & $0(20.9) b$ & $4.4(17.6) b$ & $0(20.9) \mathrm{c}$ & $2.2(23.8)$ & $91.1 \mathrm{a}$ & $77.8 \mathrm{~b}$ \\
\hline Pasir InSand & $2.2(23.8) b$ & $2.2(16.1) b$ & $2.2(23.8) \mathrm{c}$ & $4.4(26.6)$ & $95.6 \mathrm{a}$ & $64.4 \mathrm{c}$ \\
\hline Sekam TopSand & $6.7(27.6) \mathrm{a}$ & $15.5(29.3) \mathrm{a}$ & $28.9(35.9) \mathrm{a}$ & $6.7(25.5)$ & $44.4 \mathrm{~b}$ & $62.2 \mathrm{c}$ \\
\hline Sekam InSand & 8.9 (8.6) a & $37.7(38.5) a$ & $37.8(38.6) \mathrm{a}$ & $6.7(29.4)$ & $44.4 \mathrm{~b}$ & $55.6 \mathrm{~d}$ \\
\hline KK & $16.01 \mathrm{~T}$ & $29.17 \mathrm{~T}$ & $17.54 \mathrm{~T}$ & $18.95 \mathrm{~T}$ & 14.08 & 12.25 \\
\hline Notasi & $*$ & $* *$ & $*$ & th & $* *$ & $* *$ \\
\hline
\end{tabular}

Persentase kecambah hipokotil normal (\%KHN). Hasil analisis ragam pada Tabel 2 menunjukkan bahwa metode penanaman berpengaruh nyata terhadap \% KHN lot Tulangbawang tetapi tidak berpengaruh nyata terhadap \%KHN lot Pesawaran. Persentase kecambah hipokotil normal tertinggi dihasilkan oleh media sekam dengan metode penanaman top sand dan in sand yaitu $28.9 \%$ untuk top sand dan $37.8 \%$ untuk in sand. Tingginya angka \% KHN pada arang sekam dikarenakan kurangnya kemampuan media dalam menyerap air sehingga pertumbuhan embrio menjadi kecambah banyak yang menghasilkan panjang hipokotil $4-4.5 \mathrm{~cm}$.

Perlakuan metode penanaman menunjukkan hasil tidak berpengaruh nyata terhadap tolok ukur \%KHN lot Pesawaran. Metode penanaman pada kertas CD 2 baris tidak menghasilkan satupun kecambah dengan panjang hipokotil normal $(4-4.5 \mathrm{~cm})$ dan metode penanaman pada pasir top sand hanya sebesar $2.2 \%$. Sedangkan metode penanaman pada media kertas merang dengan metode penanaman 2 baris menghasilkan \% KHN yang tertinggi yaitu $17.8 \%$.

Persentase kecambah hipokotil panjang (\%KHPj). Hasil analisis ragam pada Tabel 2 menunjukkan bahwa metode penanaman berpengaruh sangat nyata terhadap \% KHPj lot Tulangbawang dan lot Pesawaran. Angka \% KHPj terendah dihasilkan oleh media arang sekam dengan metode penanaman top sand dan in sand yaitu $44.4 \%$ pada lot Tulangbawang.

Perkecambahan benih lot Pesawaran pada media sekam dengan metode penanaman top sand menunukkan angka \%KHPj sebesar $62.2 \%$. Hasil tersebut berbeda sangat nyata lebih tinggi dibandingkan penanaman pada arang sekam cara in sand yang menghasilkan \% KHP sebesar 55.6\%.
Hal ini diduga karena benih yang ditanam pada sekam dengan cara top sand lebih awal mendapatkan cahaya dibandingkan pada sekam cara in sand. Sehingga pertumbuhan kecambah pada top sand lebih cepat dan menghasilkan panjang hipokotil yang lebih baik daripada cara in sand. Keadaan tersebut juga didukung dengan hasil yang menunjukkan bahwa angka \%KHP dan \%KHN pada sekam cara top sand tidak pernah lebih tinggi daripada sekam cara in sand.

Metode penanaman pada kertas CD cara 2 baris dan 5 baris untuk benih lot Tulangbawang dan Pesawaran baik digunakan untuk menghasilkan kecambah dengan hipokotil yang panjang. Hasil ini berbeda dengan hasil penelitian Purnama (2009) yang menyatakan bahwa jenis substrat kertas merang selalu menghasilkan struktur kecambah lebih tinggi dibandingkan kertas CD (buram) pada kacang pare, buncis, kedelai dan kacang panjang. Bila pengujian menggunakan media bukan kertas, metode penanaman pada pasir top sand maupun in sand baik untuk digunakan. Untuk lot Pesawaran, metode penanaman yang baik digunakan adalah metode penanaman pada kertas CD dan kertas merang, baik dengan metode penanaman 2 maupun 5 baris. Sedangkan metode penanaman pada arang sekam cara top sand maupun in sand tidak dianjurkan untuk digunakan untuk pengujian karena banyak menghasilkan kecambah hipokotil pendek dan hanya sedikit menghasilkan kecambah hipokotil panjang.

Hasil pada Tabel 2 menunjukkan bahwa kecambah normal yang dihasilkan media kertas (CD dan merang) lebih baik dibandingkan media bukan kertas (pasir dan arang sekam), karena \%KHPj yang dihasilkan media kertas lebih tinggi daripada media bukan kertas. Kondisi perakaran 
dan diameter hipokotil kecambah dapat dilihat pada Tabel 6.

\section{Pengaruh Metode Penanaman Benih terhadap Parameter Viabilitas dan Vigor}

Pengaruh metode penanaman benih terhadap parameter viabilitas (PTM, DB, BKKN) dan vigor benih (IV dan $\mathrm{K}_{\mathrm{CT}}$ ) kecipir lot Lampung Selatan dapat dilihat pada Tabel 3. Hasil analisis ragam menunjukkan bahwa metode penanaman berpengaruh sangat nyata terhadap tolok ukur potensi tumbuh maksimum (PTM), daya berkecambah (DB), BKKN, kecepatan tumbuh $\left(\mathrm{K}_{\mathrm{CT}}\right)$ dan berpengaruh nyata terhadap tolok ukur indeks vigor.

Potensi tumbuh maksimum. Hasil analisis
ragam menunjukkan bahwa perlakuan berpengaruh sangat nyata terhadap potensi tumbuh maksimum (PTM) kecipir lot Lampung Selatan. Hasil analisis ragam menunjukkan bahwa metode penanaman pasir cara in sand dan sekam cara in sand berpengaruh sangat nyata lebih rendah dibandingkan perlakuan lainnya. Potensi tumbuh maksimum pada pasir cara in sand sebesar $74.67 \%$ dan sekam cara in sand sebesar $70.67 \%$. Rendahnya potensi tumbuh maksimum pada pasir cara in sand akibat adanya 1 ulangan menghasilkan pertumbuhan kecambah yang rendah. Pertumbuhan yang rendah ini diduga disebabkan posisi benih yang ditanam lebih dalam dari kedalaman yang seharusnya. Sehingga air yang mencapai kedalaman tersebut hanya sedikit dan mengakibatkan benih-benih vigor saja yang dapat tumbuh menjadi kecambah normal.

Daya berkecambah dan bobot kering kecambah normal. Hasil analisis ragam menunjukkan bahwa perlakuan berpengaruh sangat nyata terhadap daya berkecambah (DB) dan bobot kering kecambah normal (BKKN) benih lot Lampung Selatan. Perkecambahan pada media arang sekam dengan metode penanaman top sand maupun in sand menghasilkan DB yang berbeda nyata lebih rendah dibandingkan perlakuan lainnya. Metode penanaman top sand pada arang sekam menghasilkan daya berkecambah sebesar $52 \%$ dan metode penanaman in sand sebesar $50.67 \%$.

Bobot kering kecambah normal yang terendah juga dihasilkan oleh penanaman pada media arang sekam dengan metode penanaman top sand dan in sand. Kedua metode penanaman tersebut menghasilkan BKKN yang sama yaitu
$0.48 \mathrm{~g}$.

Penanaman pada pasir dengan metode penanaman in sand menunjukkan hasil yang rendah juga, dengan DB sebesar $62.67 \%$ dan BKKN sebesar $0.65 \mathrm{~g}$. Hasil yang rendah ini juga disebabkan alasan yang sama pada potensi tumbuh maksimum, yaitu posisi benih yang terlalu dalam mengakibatkan rendahnya pertumbuhan benih menjadi kecambah.

Indeks vigor dan kecepatan tumbuh.

Hasil analisis ragam menunjukkan bahwa perlakuan berpengaruh sangat nyata terhadap indeks vigor (IV) dan kecepatan tumbuh $\left(\mathrm{K}_{\mathrm{CT}}\right)$ kecipir lot Lampung Selatan. Perlakuan metode penanaman pasir cara top sand menghasilkan nilai tengah indeks vigor tertinggi yaitu sebesar $57.33 \%$. Hasil tersebut tidak berbeda nyata terhadap penanaman pada media kertas CD (2 dan 5 baris), kertas merang ( 2 dan 5 baris) serta metode penanaman pasir cara in sand. Nilai indeks vigor yang tinggi menunjukkan benih berkecambah lebih cepat, sehingga benih digolongkan dalam vigor kuat (Taliroso 2008).

Metode penanaman arang sekam cara top sand dan cara in sand berbeda nyata lebih rendah dibandingkan perlakuan lainnya. Rendahnya nilai indeks vigor tersebut menunjukkan bahwa media arang sekam tidak optimal untuk mendukung pertumbuhan benih kecipir menjadi kecambah normal.

Data kecepatan tumbuh kecipir lot Lampung Selatan menunjukkan bahwa metode penanaman pada pasir cara in sand, arang sekam top sand dan arang sekam in sand berbeda sangat nyata lebih rendah daripada perlakuan lainnya. Nilai kecepatan tumbuh yang rendah pada pasir in sand disebabkan karena sedikitnya benih yang tumbuh menjadi kecambah normal pada salah satu ulangan. Semakin sedikit jumlah benih yang dapat tumbuh menjadi kecambah normal, maka nilai kecepatan tumbuhnya $\left(\mathrm{K}_{\mathrm{CT}}\right)$ akan rendah karena nilai KCT dipengaruhi pertumbuhan kecambah normal per 1 etmal ( 1 etmal $=24$ jam).

Pengujian viabilitas benih kecipir lot Lampung Selatan menunjukkan bahwa metode penanaman benih pada media kertas (CD dan merang) lebih baik daripada media bukan kertas (pasir dan arang sekam). Hal ini ditunjukkan oleh PTM, DB, BKKN, IV dan $\mathrm{K}_{\mathrm{CT}}$ yang lebih tinggi pada media kertas dibandingkan media bukan kertas. 
Tabel 3. Pengaruh metode penanaman terhadap PTM, DB, BKKN, IV, dan $\mathrm{K}_{\mathrm{CT}}$ benih kecipir lot Lampung Selatan

\begin{tabular}{lrrrrr}
\hline \multirow{2}{*}{ Perlakuan } & \multicolumn{5}{c}{ Lot Lampung Selatan } \\
\cline { 2 - 6 } & PTM $(\%)$ & DB $(\%)$ & BKKN $(\mathrm{g})$ & IV $(\%)$ & KCT $(\% /$ etm $)$ \\
\hline CD 2 baris & $96.00 \mathrm{a}$ & $80.00 \mathrm{a}$ & $0.86 \mathrm{a}$ & $45.33 \mathrm{a}$ & $13.03 \mathrm{a}$ \\
CD 5 baris & $92.00 \mathrm{a}$ & $85.33 \mathrm{a}$ & $0.96 \mathrm{a}$ & $52.00 \mathrm{a}$ & $13.67 \mathrm{a}$ \\
Merang 2 baris & $97.33 \mathrm{a}$ & $93.33 \mathrm{a}$ & $1.09 \mathrm{a}$ & $49.33 \mathrm{a}$ & $14.70 \mathrm{a}$ \\
Merang 5 baris & $93.33 \mathrm{a}$ & $85.33 \mathrm{a}$ & $0.85 \mathrm{a}$ & $45.33 \mathrm{a}$ & $13.37 \mathrm{a}$ \\
Pasir topsand & $98.67 \mathrm{a}$ & $94.67 \mathrm{a}$ & $1.10 \mathrm{a}$ & $57.33 \mathrm{a}$ & $15.80 \mathrm{a}$ \\
Pasir insand & $74.67 \mathrm{c}$ & $62.67 \mathrm{~b}$ & $0.65 \mathrm{~b}$ & $46.67 \mathrm{a}$ & $9.47 \mathrm{~b}$ \\
Sekam topsand & $84.00 \mathrm{~b}$ & $52.00 \mathrm{c}$ & $0.48 \mathrm{c}$ & $29.33 \mathrm{~b}$ & $8.53 \mathrm{~b}$ \\
Sekam insand & $70.67 \mathrm{c}$ & $50.67 \mathrm{c}$ & $0.48 \mathrm{c}$ & $37.33 \mathrm{~b}$ & $8.23 \mathrm{~b}$ \\
\hline KK & 4.19 & 15.46 & 23.6 & 23.85 & 16.14 \\
\hline Notasi & $* *$ & $* *$ & $* *$ & $*$ & $* *$ \\
\hline
\end{tabular}

Keterangan : *: Berbeda nyata pada taraf 5\%; **: Berbeda sangat nyata pada taraf 1\%; PTM: Potensi tumbuh maksimum; DB : Daya berkecambah; BKKN: Bobot kering kecambah normal; IV: Indeks vigor; KCT: Kecepatan tumbuh); KK: Koefisien keragaman

Pengaruh metode penanaman benih terhadap parameter viabilitas dan vigor benih kecipir lot Tulangbawang dapat dilihat pada Tabel 4. Hasil analisis ragam menunjukkan bahwa metode penanaman berpengaruh sangat nyata terhadap tolok ukur potensi tumbuh maksimum (PTM), daya berkecambah (DB), BKKN, kecepatan tumbuh $\left(\mathrm{K}_{\mathrm{CT}}\right)$ dan berpengaruh nyata terhadap tolok ukur indeks vigor (IV).

Potensi tumbuh maksimum. Hasil penelitian menunjukkan bahwa metode penanaman pasir cara top sand dan kertas CD cara 2 baris menunjukkan nilai tengah tertinggi terhadap potensi tumbuh maksimum, yaitu $100 \%$. Hasil tersebut tidak berbeda nyata terhadap metode penanaman kertas CD cara 5 baris, merang (cara 2 baris dan 5 baris) dan pasir cara in sand. Sedangkan metode penanaman arang sekam cara in sand menunjukkan pengaruh yang berbeda sangat nyata lebih rendah diantara semua perlakuan, yaitu sebesar $74.67 \%$.

Daya berkecambah dan bobot kering kecambah normal. Data daya berkecambah lot Tulangbawang menunjukkan bahwa metode penanaman $C D$ cara 2 baris menghasilkan nilai DB tertinggi yaitu $97.33 \%$, namun tidak berbeda nyata dengan metode penanaman pada kertas CD cara 5 baris, merang (cara 2 dan 5 baris) serta pasir cara top sand dan in sand. Sedangkan metode penanaman pada media arang sekam cara top sand dan cara in sand menunjukkan pengaruh yang berbeda sangat nyata lebih rendah terhadap DB kecipir lot Tulangbawang.

Nilai bobot kering kecambah normal (BKKN) kecipir lot Tulangbawang menunjukkan bahwa metode penanaman media arang sekam cara top sand dan cara in sand berbeda sangat nyata lebih rendah terhadap BKKN dibandingkan perlakuan lainnya. Rendahnya nilai BKKN juga dipengaruhi rendahnya nilai DB yang dihasilkan melalui metode penanaman pada media arang sekam. Hal ini berarti bahwa media arang sekam dengan metode penanaman top sand dan in sand tidak baik digunakan untuk pengujian benih kecipir lot Tulangbawang.

Indeks vigor dan kecepatan tumbuh. Perlakuan metode penanaman memberikan pengaruh yang nyata terhadap nilai indeks vigor benih kecipir lot Tulangbawang. Nilai tengah indeks vigor tertinggi dihasilkan metode penanaman media kertas CD cara 2 baris, yaitu sebesar $74.67 \%$. Nilai indeks vigor tersebut tidak berbeda nyata terhadap perlakuan lainnya kecuali untuk metode penanaman pada media arang sekam cara top sand dan in sand, yang masingmasing menghasilkan $41.33 \%$ untuk top sand dan $37.33 \%$ untuk in sand.

Nilai kecepatan tumbuh juga menunjukkan hasil yang serupa dimana metode penanaman media arang sekam cara top sand dan cara in sand berbeda nyata lebih rendah dibandingkan perlakuan lainnya. Berdasarkan seluruh data pada Tabel 4, dapat disimpulkan bahwa metode penanaman pada media arang sekam cara top sand maupun in sand tidak baik digunakan untuk pengujian benih kecipir lot Tulangbawang.

Pengujian viabilitas benih kecipir lot Tulangbawang menunjukkan bahwa metode penanaman benih pada media kertas (CD dan merang) lebih baik daripada media bukan kertas (pasir dan arang sekam). Hal ini ditunjukkan oleh PTM, DB, BKKN, IV dan KCT yang lebih tinggi pada media kertas dibandingkan media bukan kertas. 
Tabel 4. Pengaruh metode penanaman terhadap PTM, DB, BKKN, IV dan KCT benih kecipir lot Tulangbawang

\begin{tabular}{lrrrrr}
\hline \multirow{2}{*}{ Perlakuan } & \multicolumn{5}{c}{ Lot Tulangbawang } \\
\cline { 2 - 6 } & PTM $(\%)$ & DB $(\%)$ & BKKN $(\mathrm{g})$ & IV $(\%)$ & KCT $(\% /$ etm $)$ \\
\hline CD 2 baris & $100.00 \mathrm{a}$ & $97.33 \mathrm{a}$ & $1.13 \mathrm{a}$ & $74.67 \mathrm{a}$ & $17.00 \mathrm{a}$ \\
CD 5 baris & $97.33 \mathrm{a}$ & $94.67 \mathrm{a}$ & $1.07 \mathrm{a}$ & $64.00 \mathrm{a}$ & $15.87 \mathrm{a}$ \\
Merang 2 baris & $97.33 \mathrm{a}$ & $93.33 \mathrm{a}$ & $1.02 \mathrm{a}$ & $54.67 \mathrm{a}$ & $15.50 \mathrm{a}$ \\
Merang 5 baris & $97.33 \mathrm{a}$ & $93.33 \mathrm{a}$ & $1.01 \mathrm{a}$ & $52.00 \mathrm{a}$ & $14.87 \mathrm{a}$ \\
Pasir topsand & $100.00 \mathrm{a}$ & $96.00 \mathrm{a}$ & $1.21 \mathrm{a}$ & $69.33 \mathrm{a}$ & $17.13 \mathrm{a}$ \\
Pasir insand & $94.67 \mathrm{a}$ & $84.00 \mathrm{a}$ & $1.03 \mathrm{a}$ & $65.33 \mathrm{a}$ & $15.40 \mathrm{a}$ \\
Sekam topsand & $85.33 \mathrm{~b}$ & $54.67 \mathrm{a}$ & $0.44 \mathrm{~b}$ & $41.33 \mathrm{c}$ & $9.03 \mathrm{~b}$ \\
Sekam insand & $74.67 \mathrm{c}$ & $56.00 \mathrm{~b}$ & $0.45 \mathrm{~b}$ & $37.33 \mathrm{c}$ & $9.00 \mathrm{~b}$
\end{tabular}

\begin{tabular}{lrrrrr}
\hline KK & 4.35 & 8.49 & 15.3 & 21.38 & 11.83 \\
\hline Notasi & $* *$ & $* *$ & $* *$ & $*$ & $* *$
\end{tabular}

Keterangan : *: Berbeda nyata pada taraf 5\%; **: Berbeda sangat nyata pada taraf 1\%; Angka yang diikuti oleh huruf yang sama pada kolom yang sama untuk masing-masing lot tidak berbeda nyata menurut uji DMRT pada taraf $\alpha 5 \%$.

Pengaruh metode penanaman benih terhadap parameter viabilitas dan vigor benih kecipir lot Pesawaran dapat dilihat pada Tabel 4. Hasil analisis ragam menunjukkan bahwa metode penanaman berpengaruh sangat nyata terhadap tolok ukur potensi tumbuh maksimum (PTM), daya berkecambah (DB), BKKN, kecepatan tumbuh $(\mathrm{KCT})$ dan berpengaruh nyata terhadap tolok ukur indeks vigor (IV).

Potensi tumbuh maksimum. Nilai tengah potensi tumbuh maksimum (PTM) yang dihasilkan oleh kecipir lot Pesawaran pada semua perlakuan tergolong tinggi dibandingkan potensi tumbuh maksimum yang dihasilkan pada lot Lampung Selatan dan lot Tulangbawang. Hal tersebut ditunjukkan oleh nilai PTM metode penanaman pada media arang sekam cara top sand dan in sand, masing-masing sebesar $90.67 \%$ dan $86.67 \%$. Namun hal tersebut tetap menunjukkan bahwa metode penanaman pada arang sekam cara top sand maupun in sand berbeda sangat nyata lebih rendah dibandingkan perlakuan lainnya.
Daya berkecambah dan bobot kering kecambah normal. Nilai daya berkecambah (DB) kecipir lot Pesawaran menunjukkan bahwa metode penanaman pada media kertas CD cara 2 baris memiliki nilai tengah tertinggi sebesar 98.67\%. Angka ini tidak berbeda nyata dengan perlakuan lainnya kecuali metode penanaman pada arang sekam cara top sand dan cara in sand yang menunjukkan hasil berbeda sangat nyata lebih rendah. Hasil yang sama juga terjadi terhadap tolok ukur bobot kering kecambah normal (BKKN). Nilai DB yang rendah pada media arang sekam berbanding lurus terhadap nilai BKKN-nya. Metode penanaman pada arang sekam cara top sand menghasilkan nilai BKKN sebesar $0.68 \mathrm{~g}$ dan cara in sand sebesar $0.64 \mathrm{~g}$. Kedua nilai tersebut berbeda sangat nyata lebih rendah dibandingkan perlakuan lainnya. Rendahnya nilai DB dan BKKN pada media arang sekam sekam menunjukkan bahwa media arang sekam tidak baik digunakan untuk pengujian benih kecipir lot Pesawaran.

Tabel 5. Pengaruh metode penanaman terhadap PTM, DB, BKKN, IV dan $\mathrm{K}_{\mathrm{CT}}$ benih kecipir lot Pesawaran

\begin{tabular}{lrcccc}
\hline \multirow{2}{*}{ Perlakuan } & \multicolumn{5}{c}{ Lot Pesawaran } \\
\cline { 2 - 5 } & PTM $(\%)$ & DB $(\%)$ & BKKN $(\mathrm{g})$ & IV $(\%)$ & KCT $(\% / \mathrm{etm})$ \\
\hline CD 2 baris & $100.00 \mathrm{a}$ & $98.67 \mathrm{a}$ & $1.16 \mathrm{a}$ & $66.67 \mathrm{a}$ & $17.00 \mathrm{a}$ \\
CD 5 baris & $98.67 \mathrm{a}$ & $96.00 \mathrm{a}$ & $1.06 \mathrm{a}$ & $66.67 \mathrm{a}$ & $16.30 \mathrm{a}$ \\
Merang 2 baris & $98.76 \mathrm{a}$ & $97.33 \mathrm{a}$ & $1.19 \mathrm{a}$ & $60.00 \mathrm{a}$ & $16.37 \mathrm{a}$ \\
Merang 5 baris & $100.00 \mathrm{a}$ & $93.33 \mathrm{a}$ & $1.05 \mathrm{a}$ & $46.67 \mathrm{~b}$ & $14.93 \mathrm{a}$ \\
Pasir topsand & $100.00 \mathrm{a}$ & $97.33 \mathrm{a}$ & $1.32 \mathrm{a}$ & $60.00 \mathrm{a}$ & $17.10 \mathrm{a}$ \\
Pasir insand & $97.33 \mathrm{a}$ & $89.33 \mathrm{a}$ & $1.13 \mathrm{a}$ & $65.33 \mathrm{a}$ & $15.73 \mathrm{a}$ \\
Sekam topsand & $90.67 \mathrm{~b}$ & $70.67 \mathrm{~b}$ & $0.68 \mathrm{~b}$ & $44.00 \mathrm{~b}$ & $11.60 \mathrm{~b}$ \\
Sekam insand & $86.67 \mathrm{~b}$ & $62.67 \mathrm{~b}$ & $0.64 \mathrm{~b}$ & $41.33 \mathrm{~b}$ & $10.37 \mathrm{~b}$ \\
\hline KK & 2.37 & 11.94 & 18.4 & 18.98 & 11.82 \\
\hline Notasi & $* *$ & $* *$ & $*$ & $* *$ \\
\hline Keterangan : *: Berbeda nyata pada taraf 5\%; **: Berbeda sangat nyata pada taraf 1\%; Angka yang diikuti oleh huruf yang sama pada
\end{tabular}


Indeks vigor dan kecepatan tumbuh. Metode penanaman pada media arang sekam cara top sand dan cara in sand menunjukkan pengaruh yang nyata lebih rendah terhadap indeks vigor kecipir lot Pesawaran. Demikian pula dengan tolok ukur kecepatan tumbuhnya (KCT), metode penanaman pada media arang sekam menunjukkan hasil yang berbeda sangat nyata lebih rendah dibandingkan perlakuan lainnya. Berdasarkan data pada Tabel 5, dapat disimpulkan bahwa seluruh media dengan metode penanaman apapun baik digunakan untuk pengujian benih kecipir lot Pesawaran, kecuali media arang sekam dengan penanaman cara top sand maupun in sand karena hasilnya berbeda nyata lebih rendah. Pengujian viabilitas benih kecipir lot Pesawaran menunjukkan bahwa metode penanaman benih pada media kertas (CD dan merang) lebih baik daripada media bukan kertas (pasir dan arang sekam). Hal ini ditunjukkan oleh PTM, DB, BKKN, IV dan KCT yang lebih tinggi pada media kertas dibandingkan media bukan kertas.

\section{Panjang Akar dan Diameter Hipokotil}

Akar dan batang (hipokotil) termasuk bagian penting dari struktur normal suatu kecambah selain plumula (bakal daun) dan kotiledon. Performa akar dan batang yang baik akan mempengaruhi pertumbuhan tanaman di lapangan karena adanya berkas pengangkut xilem dan floem pada bagian tersebut. Banyaknya berkas pengangkut pada tanaman berkaitan erat dengan kemampuan tanaman dalam menyalurkan air dan unsur hara yang diserap oleh akar ke seluruh bagian tanaman (Nijsse et al. 2001). Oleh karena itu, dalam keadaan ketersediaan air yang cukup, performa akar dan batang yang baik akan menghasilkan tanaman yang baik pula.

Pengukuran panjang akar dan diameter hipokotil juga dilakukan hanya pada 2 lot benih yaitu lot benih Kab.Tulangbawang dan lot benih Kab. Pesawaran. Hal ini dikarenakan ketersediaan jumlah benih pada lot benih Kab. Lampung Selatan terbatas. Hasil analisis ragam pengaruh perlakuan terhadap panjang akar dan diameter hipokotil menunjukkan bahwa metode penanaman berpengaruh sangat nyata terhadap panjang akar dan diameter hipokotil pada lot Tulangbawang dan lot Pesawaran.

Hasil analisis ragam pada panjang akar menunjukkan bahwa metode penanaman pada kertas CD cara 2 baris dan cara 5 baris maupun pada pasir cara top sand dan cara in sand, menunjukkan pengaruh yang sangat nyata lebih tinggi terhadap panjang akar lot Tulangbawang. Pada lot Pesawaran, metode penanaman pada substrat kertas CD (2 baris dan 5 baris) berpengaruh sangat nyata lebih tinggi dibandingkan perlakuan lainnya terhadap panjang akar kecambah. Hal ini menunjukkan bahwa metode penanaman pada kertas CD cara 2 dan 5 baris sangat baik dalam menghasilkan akar yang panjang.

Pengaruh metode penanaman terhadap ukuran diameter hipokotil menunjukkan bahwa hanya metode penanaman CD 2 baris yang berpengaruh sangat nyata lebih tinggi dibandingkan perlakuan lain. Dapat disimpulkan bahwa metode penanaman kertas CD 2 baris lebih baik dibandingkan metode lainnya dalam menghasilkan akar yang panjang dan diameter hipokotil yang besar.

Tabel 6. Pengaruh perlakuan terhadap panjang akar dan diameter hipokotil kecambah kecipir

\begin{tabular}{|c|c|c|c|c|}
\hline \multirow{2}{*}{ Perlakuan } & \multicolumn{2}{|c|}{ Panjang akar } & \multicolumn{2}{|c|}{ Diameter hipokotil } \\
\hline & Lot Tulangbawang & Lot Pesawaran & Lot Tulangbawang & Lot Pesawaran \\
\hline & \multicolumn{2}{|c|}{-----cm----- } & \multicolumn{2}{|c|}{-----mm----- } \\
\hline CD 2 baris & $9.74 \mathrm{a}$ & $10.02 \mathrm{a}$ & $2.69 \mathrm{a}$ & $2.65 \mathrm{a}$ \\
\hline CD 5 baris & $9.38 \mathrm{a}$ & $9.15 \mathrm{a}$ & $2.32 \mathrm{~b}$ & $2.37 \mathrm{~b}$ \\
\hline Merang 2 baris & $8.67 \mathrm{~b}$ & $8.66 \mathrm{~b}$ & $2.30 \mathrm{~b}$ & $2.41 \mathrm{~b}$ \\
\hline Merang 5 baris & $7.76 \mathrm{c}$ & $8.80 \mathrm{~b}$ & $2.27 \mathrm{~b}$ & $2.26 \mathrm{c}$ \\
\hline Pasir TopSand & $10.20 \mathrm{a}$ & $7.86 \mathrm{c}$ & $1.94 \mathrm{c}$ & $1.83 \mathrm{e}$ \\
\hline Pasir InSand & $10.17 \mathrm{a}$ & $7.41 \mathrm{~d}$ & $1.87 \mathrm{c}$ & $1.90 \mathrm{e}$ \\
\hline Sekam TopSand & $6.05 \mathrm{~d}$ & $6.68 \mathrm{e}$ & $1.92 \mathrm{c}$ & $1.90 \mathrm{e}$ \\
\hline Sekam InSand & $6.00 \mathrm{~d}$ & $7.23 \mathrm{~d}$ & $2.01 \mathrm{c}$ & $2.06 \mathrm{~d}$ \\
\hline KK $(\%)$ & 9.15 & 6.85 & 3.87 & 3.21 \\
\hline Notasi & $* *$ & $* *$ & $* *$ & $* *$ \\
\hline
\end{tabular}

Keterangan : **: Berbeda sangat nyata pada taraf 1\%; KK: Koefisien keragaman; Angka yang diikuti oleh huruf yang sama pada kolom yang sama untuk masing-masing lot tidak berbeda nyata menurut uji DMRT pada taraf $\alpha 5 \%$. 


\section{Korelasi Daya Berkecambah dan Bobot Kering Kecambah Normal}

Analisis regresi korelasi linear digunakan untuk mengetahui hubungan linear antara dua variabel $\mathrm{X}$ dan $\mathrm{Y}$. Hubungan tersebut dapat diketahui dengan nilai koefisien korelasi (r). Menurut Gomez dan Gomez (2010) nilai koefisien korelasi (r) berada diantara -1 hingga +1 . Tanda positif (+) atau negatif (-) pada nilai $r$ menunjukkan arah perubahan pada suatu peubah terhadap perubahan lainnya, sedangkan nilai koefisien korelasi yang semakin mendekati angka
-1 maupun +1 menandakan keeratan kedua variabel tersebut.

Hasil analisis korelasi regresi antara tolok ukur daya berkecambah dan bobot kering kecambah normal (BKKN) benih kecipir lot Lampung Selatan tertera pada Tabel 7. Hasil pada Tabel 7 menunjukkan bahwa seluruh metode penanaman menunjukkan korelasi yang positif antara daya berkecambah dan BKKN. Hal ini berarti bahwa seluruh metode penanaman yang digunakan untuk lot Lampung Selatan baik untuk digunakan dalam memprediksi nilai $\mathrm{BKKN}$ melalui nilai daya berkecambahnya.

Tabel 7. Nilai persamaan regresi, nilai korelasi (r) antara DB dan BKKN benih kecipir lot Lampung Selatan

\begin{tabular}{lcc}
\hline \multicolumn{1}{c}{ Perlakuan } & Persamaan & Koefisien korelasi (r) \\
\hline Kertas CD 2 baris & $\mathrm{Y}=0.009 \mathrm{x}+0.08$ & 0.97 \\
Kertas CD 5 baris & $\mathrm{Y}=0.012 \mathrm{x}-0.10$ & 0.81 \\
Kertas Merang 2 baris & $\mathrm{Y}=0.026 \mathrm{x}-1.31$ & 0.77 \\
Kertas Merang 5 baris & $\mathrm{Y}=0.006 \mathrm{x}+0.34$ & 0.96 \\
Pasir top sand & $\mathrm{Y}=0.031 \mathrm{x}-1.83$ & 0.99 \\
Pasir in sand & $\mathrm{Y}=0.006 \mathrm{x}+0.28$ & 0.99 \\
Sekam top sand & $\mathrm{Y}=0.012 \mathrm{x}-0.17$ & 0.97 \\
Sekam in sand & $\mathrm{Y}=0.014 \mathrm{x}-0.22$ & 0.99 \\
\hline
\end{tabular}

Keterangan : $\mathrm{Y}=$ Bobot kering kecambah normal; $\mathrm{x}=$ daya berkecambah; $\mathrm{r}=$ koefisien korelasi

Hasil analisis korelasi regresi antara tolok ukur DB dan BKKN benih kecipir lot Tulangbawang ditampilkan pada Tabel 8. Hasil menunjukkan bahwa pada seluruh metode perlakuan terdapat korelasi yang positif antara DB dan BKKN. Korelasi yang sangat tinggi dihasilkan oleh metode penanaman pada kertas CD cara 2 baris dan 5 baris, pasir cara top sand dan sekam cara in sand dengan nilai korelasi mendekati angka 1. Hal ini berarti dengan menggunakan keempat metode tersebut nilai
BBKN dapat diprediksi melalui nilai daya berkecambah yang dihasilkan.

Namun ada dua metode perlakuan yang menunjukkan korelasi positif namun hubungannya tidak erat, yaitu pada metode penanaman merang 2 baris dan sekam top sand yang nilai korelasinya dibawah $0.5(<50 \%)$. Korelasi yang positif namun tidak erat ini menunjukkan bahwa nilai BKKN tidak selalu dapat diprediksi melalui nilai daya berkecambahnya dengan menggunakan metode penanaman tersebut.

Tabel 8. Nilai persamaan regresi, nilai korelasi (r) antara DB dan BKKN benih kecipir lot Tulangbawang

\begin{tabular}{lcc}
\multicolumn{1}{c}{ Perlakuan } & Persamaan & Koefisien korelasi (r) \\
\hline CD 2 baris & $\mathrm{Y}=0.038 \mathrm{x}-2.58$ & 0.95 \\
CD 5 baris & $\mathrm{Y}=0.024 \mathrm{x}-1.24$ & 0.96 \\
Merang 2 baris & $\mathrm{Y}=0.015 \mathrm{x}-0.38$ & 0.44 \\
Merang 5 baris & $\mathrm{Y}=0.023 \mathrm{x}-1.15$ & 0.80 \\
Pasir TopSand & $\mathrm{Y}=0.106 \mathrm{x}-8.85$ & 0.99 \\
Pasir InSand & $\mathrm{Y}=0.017 \mathrm{x}-0.41$ & 0.77 \\
Sekam TopSand & $\mathrm{Y}=0.006 \mathrm{x}+0.09$ & 0.48 \\
Sekam InSand & $\mathrm{Y}=0.013 \mathrm{x}-0.26$ & 0.96 \\
\hline
\end{tabular}

Keterangan : $\mathrm{Y}=$ Bobot kering kecambah normal; $\mathrm{x}=$ daya berkecambah; $\mathrm{r}=$ koefisien korelasi

Hasil analisis korelasi regresi antara tolok ukur daya berkecambah (DB) dan bobot kering kecambah normal (BKKN) lot Pesawaran pada Tabel 9 menunjukkan bahwa semua metode penanaman menghasilkan korelasi yang positif antara DB dan BKKN. Hal ini menunjukkan bahwa peningkatan DB berpengaruh positif terhadap BKKN yang dihasilkan. Korelasi antara DB dan BKKN pada lot Pesawaran yang lebih erat ditunjukkan pada metode penanaman merang 5 baris dengan nilai korelasi 0.97 dan sekam top sand dengan nilai korelasi 0.96 . 
Tabel 9. Nilai persamaan regresi, nilai korelasi (r) antara DB dengan BKKN kecipir lot Pesawaran

\begin{tabular}{lcc}
\hline \multicolumn{1}{c}{ Perlakuan } & Persamaan & Koefisien korelasi $(\mathrm{r})$ \\
\hline CD 2 baris & $\mathrm{Y}=0.026 \mathrm{x}-1.43$ & 0.74 \\
CD 5 baris & $\mathrm{Y}=0.009 \mathrm{x}+1.98$ & 0.83 \\
Merang 2 baris & $\mathrm{Y}=0.015 \mathrm{x}-0.33$ & 0.69 \\
Merang 5 baris & $\mathrm{Y}=0.040 \mathrm{x}-2.70$ & 0.97 \\
Pasir TopSand & $\mathrm{Y}=0.089 \mathrm{x}-7.32$ & 0.83 \\
Pasir InSand & $\mathrm{Y}=0.019 \mathrm{x}-0.62$ & 0.51 \\
Sekam TopSand & $\mathrm{Y}=0.015 \mathrm{x}-0.43$ & 0.96 \\
Sekam InSand & $\mathrm{Y}=0.008 \mathrm{x}+0.11$ & 0.75 \\
\hline
\end{tabular}

Keterangan : $\mathrm{Y}=$ Bobot kering kecambah normal; $\mathrm{x}=$ daya berkecambah; $\mathrm{r}=$ koefisien korelasi.

\section{KESIMPULAN}

Hasil pengujian menunjukkan bahwa metode penanaman pada kertas $\mathrm{CD}$ cara 2 dan 5 baris serta kertas merang ( 2 dan 5 baris) sangat berpengaruh untuk menghasilkan jumlah kecambah dengan ukuran hipokotil yang panjang. Metode penanaman pada kertas CD ( 2 dan 5 baris) serta kertas merang dengan cara 2 baris dapat digunakan untuk pengujian mutu fisiologis benih kecipir karena menghasilkan nilai tengah yang baik dan berpengaruh nyata terhadap tolok ukur PTM, DB, BKKN, IV dan $\mathrm{K}_{\mathrm{CT}}$. Bila pengujian dilakukan tanpa substrat kertas, metode penanaman pada pasir secara top sand dapat digunakan sebagai metode penanaman alternatif dalam pengujian benih kecipir. Berdasarkan data korelasi antara DB dan BKKN, metode penanaman pada kertas CD 2 baris dan 5 baris selalu memiliki nilai korelasi yang tinggi, sehingga metode penanaman pada kertas CD cara 2 baris maupun 5 baris lebih baik dibandingkan perlakuan lainnya.

\section{DAFTAR PUSTAKA}

[Ditjen Pangan] Direktorat Jenderal Tanaman Pangan. 2009. Persyaratan dan Tatacara sertifikasi benih bina tanaman pangan. Jakarta (ID).

Gomez, A.A., Gomez, K/A. 2010. Prosedur Statistik untuk Penelitian Pertanian Edisi Kedua. Jakarta (ID): UI Press.

Handayani, T. 2013. Kecipir (Psophocarpus tetragonolobus L.), potensi lokal yang terpinggir. IPTEK Tanaman Sayuran, No.001: 1-8.

[ISTA] International Seed Testing Association. 2014. International Rules for Seed Testing. Switzerland $(\mathrm{CH})$ : ISTA.

Nijsse, J, van der Heijden, G.W.A.M., Van Ieperen, W., Keijzer, C.J., Van Meeteren, U. 2001. Xylem hydraulic conductivity related to conduit dimensions along chrysanthemum stems. $J$ of Exp Bot. 52:319-327.

Purnama, D. 2009. Pengaruh Jenis dan Jumlah Substrat Kertas terhadap Viabilitas Benih Kacang Buncis, Pare, Kedelai dan Kacang Panjang. Skripsi. Bogor (ID): Institut Pertanian Bogor.

Rahayu, A.D. 2015. Pengamatan Uji Daya Berkecambah, Optimalisasi Substrat Perkecambahan, dan Pematahan Dormansi Benih Kecipir (Psophocarpus tetragonolobus L. DC). Skripsi. Bogor (ID):Institut Pertanian Bogor.

Taliroso, D. 2008. Deteksi Status Vigor Benih Kedelai (Glycine max L.merr) Melalui Metoda Uji Daya Hantar Listrik. Skripsi. Bogor (ID): Institut Pertanian Bogor.

Widajati, E., Murniati, E., Palupi, E.R., Kartika, T., Suhartanto, M.R., Qadir, A. 2013. Dasar Ilmu dan Teknologi Benih. Bogor (ID):IPBPress 